\title{
Litterfall and Element Return in an Abies faxoniana Forest in Tibet-A Five-Year Study
}

\author{
Weiting Wu ${ }^{1,2}$, Yabei Zhang ${ }^{1,3}$, Lifeng Wang ${ }^{1}$, Yu Zhou ${ }^{1}$, Yamei Chen ${ }^{4}$, Shuqin He ${ }^{1}$, Jian Zhang ${ }^{1}$ \\ and Yang Liu ${ }^{1, *(\mathbb{D})}$ \\ 1 Long-Term Research Station of Alpine Ecosystems, Key Laboratory of Ecological Forestry Engineering of \\ Sichuan Province, College of Forestry, Sichuan Agricultural University, Chengdu 611130, China; \\ w18200521109@163.com (W.W.); zyb302515@163.com (Y.Z.); scwanglf@163.com (L.W.); \\ cn99zhouyu@163.com (Y.Z.); hesq@sicau.edu.cn (S.H.); sicauzhangjian@163.com (J.Z.) \\ 2 College of Soil and Water Conservation, Beijing Forestry University, Beijing 100083, China \\ 3 College of Resource and Environment Science, Xinjiang University, Urumqi 830046, China \\ 4 Key Laboratory of Southwest China Wildlife Resources Conservation, China West Normal University, \\ Ministry of Education, Nanchong 637009, China; yameichen316@163.com \\ * Correspondence: sicauliuyang@163.com
}

check for updates

Citation: Wu, W.; Zhang, Y.; Wang, L.; Zhou, Y.; Chen, Y.; He, S.; Zhang, J.; Liu, Y. Litterfall and Element Return in an Abies faxoniana Forest in Tibet-A Five-Year Study. Forests 2021, 12, 1577. https://doi.org/ 10.3390/f12111577

Academic Editors: Choonsig Kim, Christopher Gough and Chris Peterson

Received: 30 September 2021 Accepted: 12 November 2021 Published: 17 November 2021

Publisher's Note: MDPI stays neutral with regard to jurisdictional claims in published maps and institutional affiliations.

Copyright: (c) 2021 by the authors. Licensee MDPI, Basel, Switzerland. This article is an open access article distributed under the terms and conditions of the Creative Commons Attribution (CC BY) license (https:// creativecommons.org/licenses/by/ $4.0 /)$.

\begin{abstract}
Forest litter is the main contributor to soil fertility and the main carrier of circulating material and energy in forest ecosystems. Abies faxoniana (Minjiang fir) is one of the dominant species in alpine forest ecosystems. Its litter input plays important roles in soil organic matter formation and biogeochemical cycles in these ecosystems, but the annual litterfall pattern and its components remain largely unknown. To determine the litter input and nutrient return of $A$. faxoniana, we measured the litterfall and element (carbon $(\mathrm{C})$, nitrogen $(\mathrm{N})$, phosphorus $(\mathrm{P})$, potassium $(\mathrm{K})$, calcium $(\mathrm{Ca})$, sodium $(\mathrm{Na})$, magnesium $(\mathrm{Mg})$, aluminium $(\mathrm{Al})$, iron $(\mathrm{Fe})$, and manganese $(\mathrm{Mn})$ ) contents of different litter components (branches, leaves and epiphytes) from 2016 to 2020. The results showed that the annual litterfall in the A. faxoniana forest ranged from 2055.96 to $5384.15 \mathrm{~kg} \cdot \mathrm{ha}^{-1} \cdot \mathrm{a}^{-1}$, and the average mass proportions of branches, leaves and epiphytes were $30.12 \%, 62.18 \%$ and $7.7 \%$, respectively. The litterfall yield varied significantly with time and component; not only was the yield of litter in the nongrowing season higher than that in the growing season, but it also exhibited dramatic interannual variations. We also found that time had significant effects on the contents of all elements except for $\mathrm{Ca}$ in the litter. The return and input amounts of each element followed the same dynamics, which closely resembled a bimodal pattern. Moreover, there was significant interannual variability in the returned amounts of each element. The ranges of annual returns of $\mathrm{C}, \mathrm{N}$ and $\mathrm{P}$ were 744.80 2275.12, 19.80 59.00 and 1.03 2.81 kg.ha ${ }^{-1} \cdot \mathrm{a}^{-1}$, respectively. The ranges of annual returns of $\mathrm{K}, \mathrm{Ca}, \mathrm{Na}, \mathrm{Mg}$, Al, Fe and Mn were 0.91 2.00, 7.04 18.88, 0.13 0.58, 0.33 1.20, 0.55 2.29, 0.41 1.37 and $0.16 \sim 0.48 \mathrm{~kg} \cdot \mathrm{ha}^{-1} \cdot \mathrm{a}^{-1}$, respectively, reflecting a seasonal double-peak pattern. These results have important implications for understanding the biogeochemical cycles and material migration processes in alpine forest ecosystems.
\end{abstract}

Keywords: litter production; elements; nutrient return; alpine forest; Abies faxoniana

\section{Introduction}

Forest litter is the metabolic product of forest plants and their components (leaves, branches, flowers, fruits, seeds, bark, roots and epiphytes) undergoing growth and development and is the main contributor to soil fertility and the main carrier of circulating material and energy flow in forest ecosystems [1]. During the process of plant growth, the elements contained in litter will be returned to the soil after decomposition and release, where they are available for plant absorption and utilization. The quality and quantity of litter are closely related to soil fertility and are key characteristics of forest ecological system services [2-5]. Moreover, as the basic carrier of matter and energy flow, forest litter affects 
the capacity of carbon sink storage [6,7]. Moreover, litter plays a particularly important role in maintaining soil fertility and promoting the material circulation and nutrient balance of forest ecosystems. Therefore, due to its important role in regulating ecosystem functions and services, it is necessary to understand aboveground litter production and the amounts of elements returned to terrestrial ecosystems [8,9].

Carbon $(\mathrm{C})$ and nitrogen $(\mathrm{N})$ may be the main factors limiting the growth and productivity of alpine forests; for example, the distribution of the alpine treeline is related to the $\mathrm{C}$ limitation [10]. $\mathrm{C}$ is the basic building block of living organisms, accounting for more than $50 \%$ of all their elements [11]. Various elements play different roles in the physiological processes of plant growth and development and are also an indispensable part of plants. Some metal elements are essential for biological enzyme production and function and play important roles as regulatory factors to maintain the normal life activities of plants [12,13]. Elements are not only involved in plant growth (e.g., magnesium (Mg) harvests solar energy by occupying the central position in the chlorophyll structure, and calcium (Ca) and $\mathrm{Mg}$ can drive leaf postmortem degradation, with manganese (Mn) having especially strong effects on lignin degradation [14,15]) but also critical for consumers (e.g., the cell concentration and membrane voltage of decomposers must be maintained by a sodium (Na) pump [16]). When any of the critical steps of metal and nutrient homeostasis are disrupted, the cells become dysfunctional, leading to disease (e.g., potassium (K) deficiency in plants causes the old leaves to appear yellow or exhibit white spots, leading to spot rot [17]). The metal element content can also affect the decomposition rate of litter [18,19].

Abies faxoniana (Minjiang fir) is the dominant tree species of the subalpine coniferous forest that is distributed in the southwest mountains of China, and this species is always distributed at high altitudes near the alpine treeline. The alpine treeline ecotone is sensitive to climate change. Although we have performed considerable research on the biogeochemical processes of litter decomposition across the alpine treeline ecotone [20-24], the litterfall and element return of alpine forests has not yet been described [25-27]. What is the extent of litterfall inputs and element return in the alpine Minjiang fir forest? What are the dynamics of seasonal or interannual patterns? Few studies have focused on monitoring long-term litterfall patterns in subalpine forests. Therefore, five years of litterfall yield and returned amounts of elements $(\mathrm{C}, \mathrm{N}, \mathrm{P}, \mathrm{K}, \mathrm{Ca}, \mathrm{Na}, \mathrm{Mg}$, aluminium ( $\mathrm{Al}$ ), iron (Fe) and $\mathrm{Mn}$ ) in a Minjiang fir forest were measured from 2016 to 2020 to elucidate the characteristics of seasonal pattern (growing season and nongrowing season) and interannual dynamics of litterfall. This study fills a gap in our understanding of the biogeochemical cycle and material migration processes in subalpine forest ecosystems.

\section{Materials and Methods}

\subsection{Study Site}

The Long-term Research Station of Alpine Forest Ecosystems is located in Miyaluo Nature Reserve, Sichuan, Southwest China $\left(\sim 31^{\circ} 51^{\prime} \mathrm{N}, 102^{\circ} 41^{\prime}\right.$ E) [23]. This region is within a transitional area between the Tibetan Plateau and the Sichuan Basin. There are mixed coniferous broadleaved forests, dark coniferous forests, alpine shrub woodlands, and successive alpine meadows from the valley to the ridge, with remarkable vertical zonality and a snow belt above $4500 \mathrm{~m}$ a.s.l. The weather is cool in summer and cold in winter because of the region's plateau topography. In January, the average temperature is $-8^{\circ} \mathrm{C}$, and in July, it is $12.6^{\circ} \mathrm{C}$. The annual rainfall is approximately $700 \sim 1400 \mathrm{~mm}$. The snow-covered season starts in November and lasts until the end of April (approximately 6 or 7 months) in the alpine zone $[15,24]$. The region is dominated by subalpine dark coniferous forests, and the main tree genera include Abies, Picea, Larix, Sabina, Pinus, etc. The soils are Cryumbreps (United States Department of Agriculture Soil Taxonomy) in the coniferous forest. The alpine treeline, which is located around the upper elevational boundary of the coniferous forest, is at approximately $4000 \mathrm{~m}$ a.s.l.

The experimental site is located in a primary coniferous forest, and the elevation is $3900 \mathrm{~m}$. The exposure is east by $5^{\circ}$ north with an average slope of $36^{\circ}$. The DBH of mature 
trees is $45 \pm 4 \mathrm{~cm}$. The average heights of trees, shrubs and herbaceous plants are $22 \mathrm{~m}, 8 \mathrm{~m}$ and $0.11 \mathrm{~m}$, respectively. The percent cover of trees, shrubs and herbaceous plants are $90 \%$, $5 \%$ and $20 \%$, respectively. The average thicknesses of the moss layer and litter layer are approximately $10 \mathrm{~cm}$ and $9 \mathrm{~cm}$, respectively. The dominant species mainly include Abies faxoniana, Sorbus hupehensis and Rhododendron pachytrichum. The common epiphyte of fir is Usnea diffracta Vain, which attaches to branches of spruce and fir in dark, humid coniferous forests.

\subsection{Sample Plot Design}

In October 2015, three sample plots of $30 \mathrm{~m} \times 30 \mathrm{~m}$ were established in this primary forest. Five nylon litter traps with dimensions of $1 \mathrm{~m} \times 1 \mathrm{~m}$, a net aperture of $1 \mathrm{~mm}$ and a height of $1.2 \mathrm{~m}$ were placed at the four corners and in the centre of each sample plot. Subsequently, litter was collected in early May and late October from 2016 to 2020 according to our decomposition experiment arrangement, in which litterbags were sampled twice a year. Meanwhile, air temperature and rainfall were measured by the weather station of the Long-term Research Station of Alpine Forest Ecosystems from 2016-2020 (Figure 1). Figure 1 shows the monthly dynamics of the mean air temperature and rainfall. In this region, the growing season is from May to October, and the nongrowing season is from November to April [15].

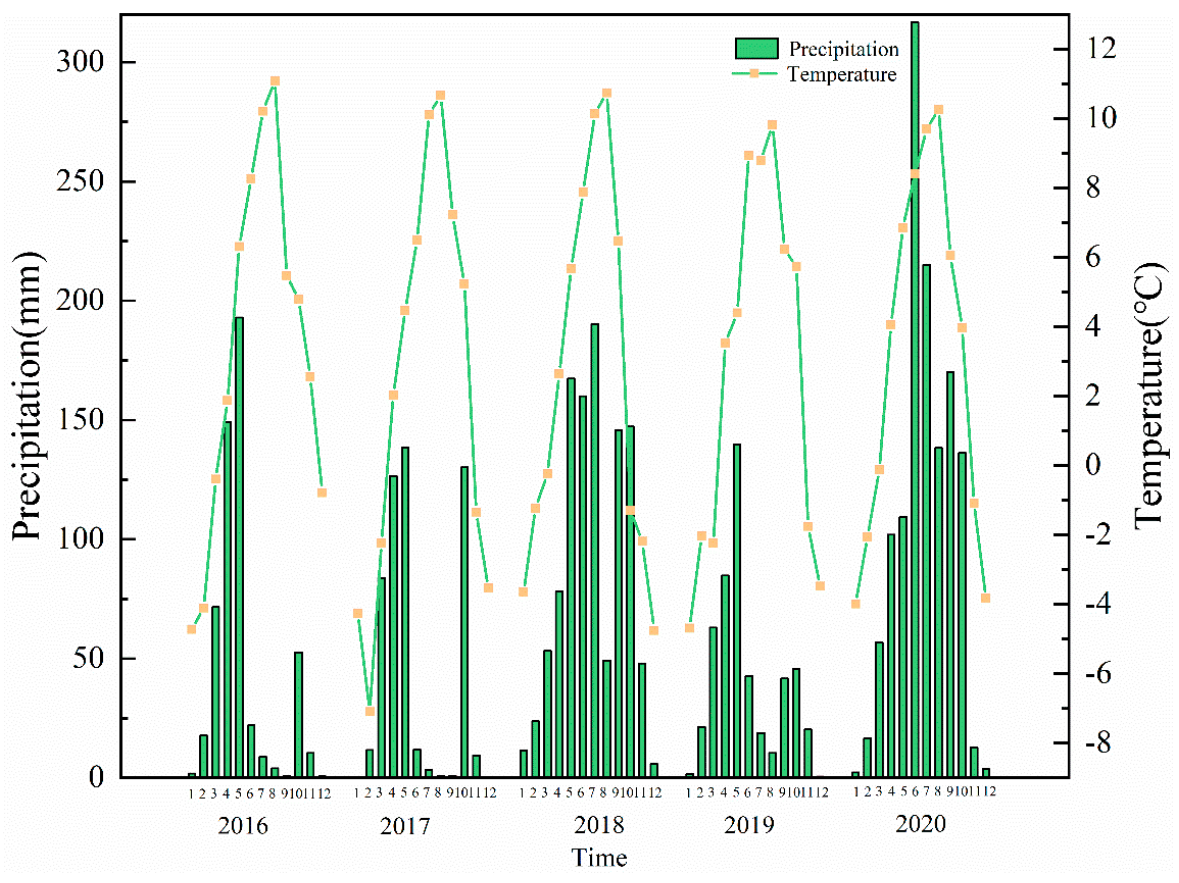

Figure 1. Mean monthly air temperature and rainfall of the Long-term Research Station of Alpine Forest Ecosystems from 2016-2020.

\subsection{Litter Collection and Processing}

Litter samples were collected from the 15 nylon litter traps located in the 3 sample plots in the Minjiang fir (Abies faxoniana) forest. After soil and other debris were removed, the litter samples were put into nylon bags and transported to a dry and ventilated location for natural air drying. As there were few flowers, seeds and fruits in the samples and they were only rarely collected, they were not included in the analysis. Litter was grouped into one of three components (branches, leaves and epiphytes) and then oven dried to constant weight at $65^{\circ} \mathrm{C}$. The litter input amount was determined for each component by weighing the dried samples. Then, the samples were crushed and screened with a sieve (diameter: $0.15 \mathrm{~mm}$ ), and the resulting material was used to analyse the contents of $C$, $\mathrm{N}, \mathrm{P}, \mathrm{K}, \mathrm{Ca}, \mathrm{Na}, \mathrm{Mg}, \mathrm{Al}, \mathrm{Fe}$ and $\mathrm{Mn}$ in the litter types. The $\mathrm{C}$ contents of the litter were 
determined using the $\mathrm{H}_{2} \mathrm{SO}_{4}-\mathrm{K}_{2} \mathrm{Cr}_{2} \mathrm{O}_{7}$ oxidation method, the $\mathrm{N}$ content was determined by the Kjeldahl acid-digestion method [27], and the P content was determined using the molybdenum blue method [28]. After the sample was digested by the nitrate acidperchloric acid elimination method, the metal element content was determined by atomic absorption spectrophotometry [29].

\subsection{Data Analysis}

Litter yield and litter element return were standardized with the following formula:

$$
\mathrm{M}=\frac{\mathrm{M}_{1}}{\mathrm{~S}}
$$

where $\mathrm{M}$ is litterfall yield per unit area $\left(\mathrm{kg} \cdot \mathrm{ha}^{-1}\right), \mathrm{M}_{1}$ is the weight of the collected litter $(\mathrm{kg})$, and $\mathrm{S}$ is the unit area (ha).

$$
\mathrm{Me}=\mathrm{Ce} \times \mathrm{M} \times 10^{-3}
$$

where Me is the element return amount $\left(\mathrm{kg} \cdot \mathrm{ha}^{-1}\right), \mathrm{Ce}$ is the measured element content in the litter $\left(\mathrm{g} \cdot \mathrm{kg}^{-1}\right)$, and ha10 ${ }^{-3}$ is the unit conversion factor.

To understand the characteristics of the interannual and seasonal patterns of litterfall and its components, interannual and seasonal litter yields and elemental contents were analysed. First, nonparametric tests and independent sample $\mathrm{T}$ tests were used to determine whether the data were normally distributed. Then, correlation analysis was applied to litter production and climate in study area, which including seasonal and annual mean temperature and total precipitation (Table 1). The litter input of different components was tested by the LSD test (Figure 2); independent sample T tests and the LSD test were used to analyse the litter input in different seasons (Figure 3); the Kruskal-Wallis test was used to analyse the contents of various elements in different components of the litter (Figure 4); and repeated-measures ANOVA, the LSD test and the Kruskal-Wallis test were used to assess the litterfall yield, contents of C, N, P and metal elements and the return amount of the litter (Table 2).

Table 1. Correlation between the amount of litterfall and air temperature and precipitation.

\begin{tabular}{cccccc}
\hline \multirow{2}{*}{ Litter Amount } & \multicolumn{2}{c}{ Air Temperature } & \multicolumn{2}{c}{ Precipitation } \\
\cline { 3 - 6 } & & $\mathbf{R}$ & $\boldsymbol{p}$ & $\mathbf{R}$ & $\boldsymbol{p}$ \\
\hline \multirow{4}{*}{ Seasonal } & Epiphytes & 0.264 & 0.461 & 0.132 & 0.717 \\
& Leaves & 0.213 & 0.555 & 0.253 & 0.480 \\
& Branches & -0.163 & 0.653 & -0.235 & 0.513 \\
& Total & 0.430 & 0.215 & -0.460 & 0.843 \\
\hline \multirow{4}{*}{ Annual } & Epiphytes & -0.112 & 0.857 & -0.442 & 0.457 \\
& Leaves & -0.449 & 0.448 & -0.034 & 0.956 \\
& Branches & -0.277 & 0.652 & -0.556 & 0.331 \\
& Total & -0.123 & 0.181 & -0.812 & 0.095 \\
\hline
\end{tabular}




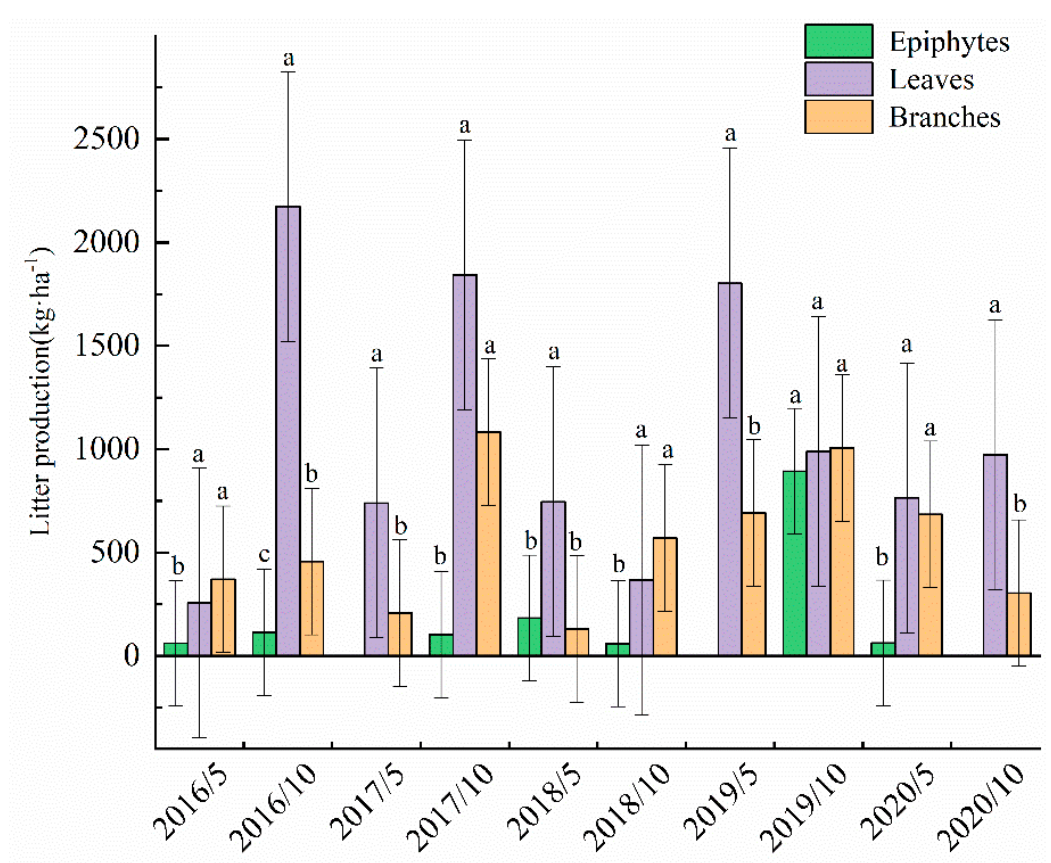

Figure 2. Inputs of three litter components in the A. faxoniana forest from 2016 to 2020 . The values represent the means $\pm \mathrm{SD} ; n=45$; different lowercase letters indicate that there were significant differences in litter production by different components at the same time $(p<0.05)$.

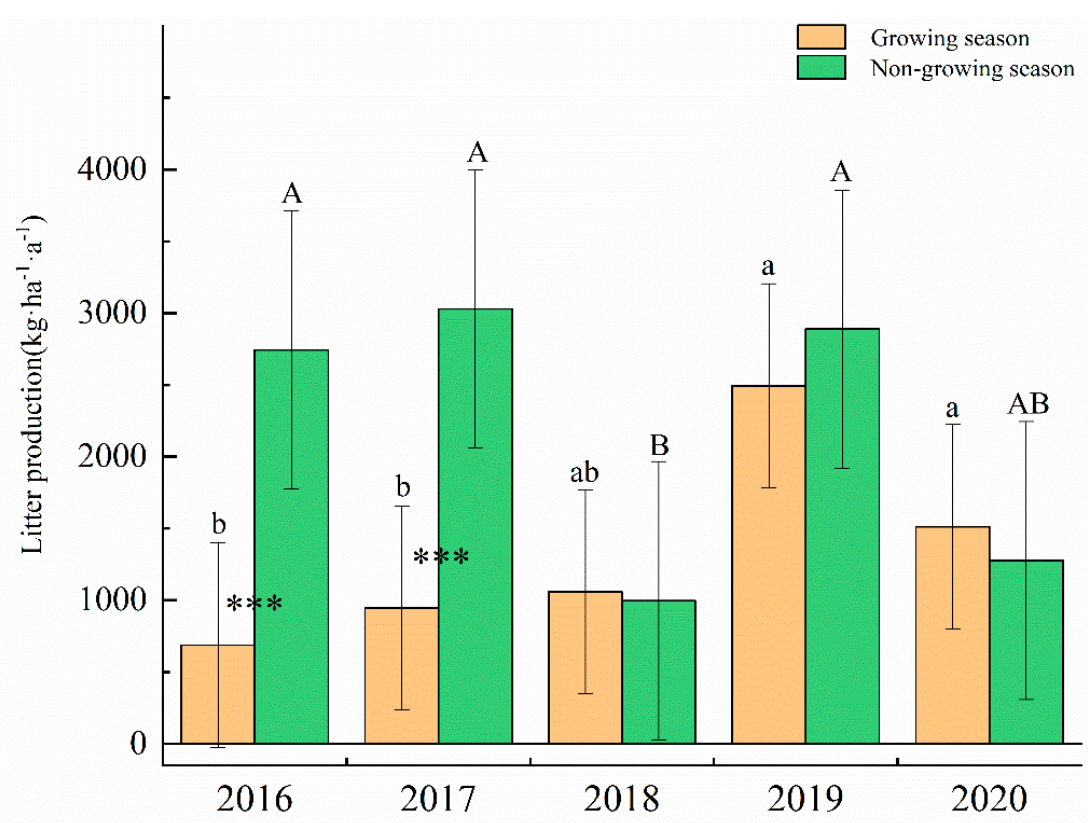

Figure 3. Seasonal dynamics of litter input in A. faxoniana forest from 2016 to 2020 . The values represent the means $\pm \mathrm{SD} ; n=45$. Different capital letters indicate significant differences in the litter amount in the nongrowing season; different lowercase letters indicate significant differences in the litter amount in the growing season; ${ }^{* * *}$ indicates significant differences in seasonal litter production $(p<0.001)$. 


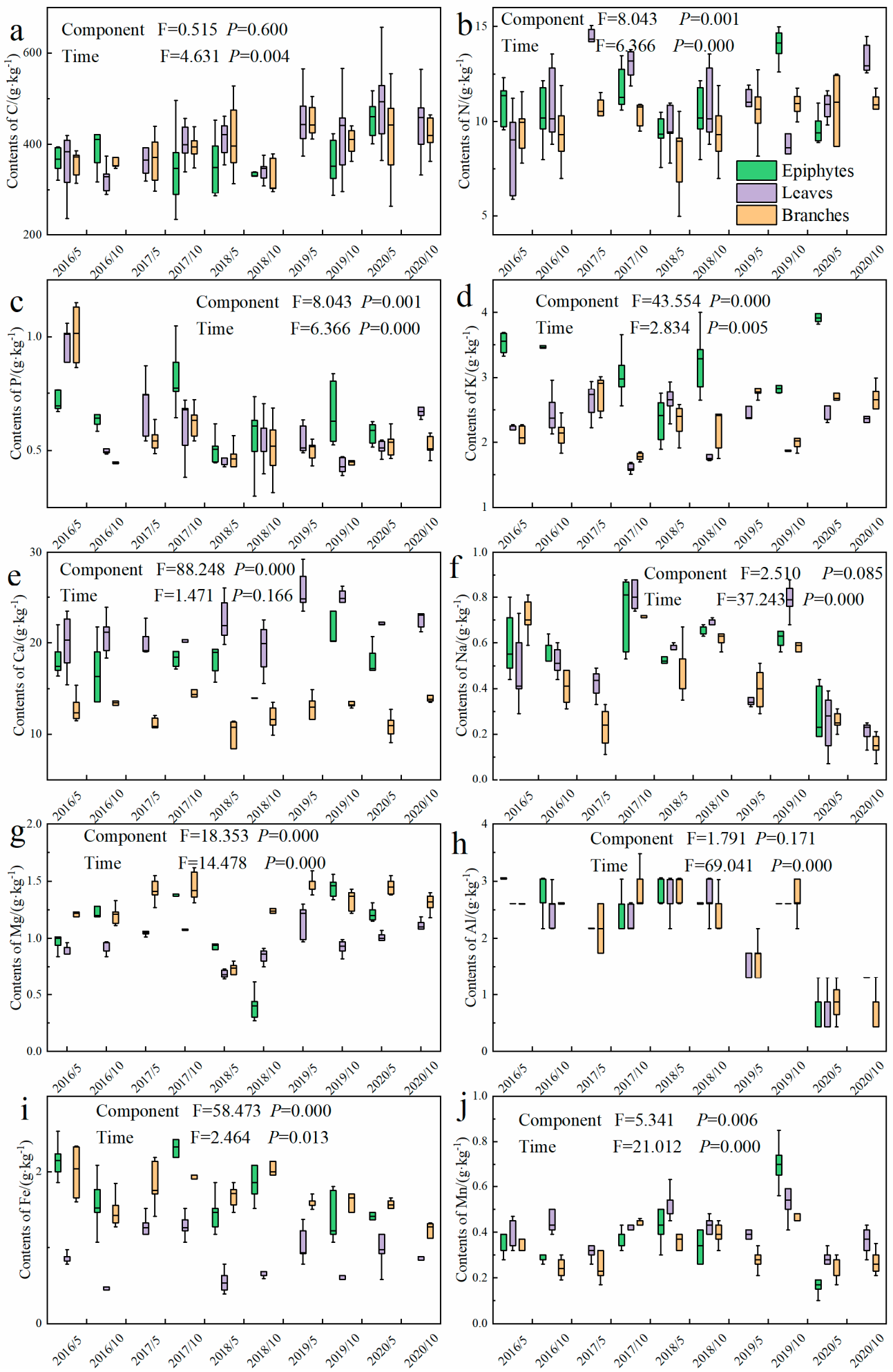

Figure 4. Litterfall element contents in A. faxoniana forest from 2016 to 2020. (a): The C contents of the litter; (b): the $\mathrm{N}$ contents of the litter; $(\mathbf{c})$ : the P contents of the litter; $(\mathbf{d})$ : the K contents of the litter; (e): the Ca contents of the litter; (f): the Na contents of the litter; (g): the Mg contents of the litter; (h): the Al contents of the litter; (i): the Fe contents of the litter; and (j): the Mn contents of the litter. The values represent the means $\pm \mathrm{SD} ; n=45$. 
Table 2. The amount of each element returned by litterfall in the A. faxoniana forest from 2016 to 2020.

\begin{tabular}{|c|c|c|c|c|c|}
\hline \multirow{2}{*}{ Element } & \multicolumn{4}{|c|}{ Element Returned Amount $\left(\mathrm{kg} \cdot \mathrm{ha}^{-1} \cdot \mathrm{a}^{-1}\right)$} & \multirow[b]{2}{*}{2020} \\
\hline & 2016 & 2017 & 2018 & 2019 & \\
\hline $\mathrm{C}$ & $1179.63 \mathrm{~b}$ & $1569.14 \mathrm{ab}$ & $744.80 \mathrm{~b}$ & $2275.12 \mathrm{a}$ & $1243.31 \mathrm{ab}$ \\
\hline $\mathrm{N}$ & $30.55 \mathrm{~d}$ & $49.00 \mathrm{~b}$ & $19.80 \mathrm{~d}$ & $59.00 \mathrm{a}$ & $32.40 \mathrm{c}$ \\
\hline $\mathrm{P}$ & $2.04 \mathrm{ab}$ & $2.50 \mathrm{a}$ & $1.03 \mathrm{c}$ & $2.81 \mathrm{a}$ & $1.61 \mathrm{~b}$ \\
\hline $\mathrm{K}$ & $1.94 \pm 0.96 \mathrm{a}$ & $0.91 \pm 0.69 \mathrm{~b}$ & $1.26 \pm 1.85 \mathrm{ab}$ & $2.00 \pm 1.40 \mathrm{a}$ & $1.46 \pm 0.89 \mathrm{ab}$ \\
\hline $\mathrm{Ca}$ & $18.88 \pm 12.50 \mathrm{a}$ & $7.04 \pm 5.78 b$ & $9.85 \pm 16.07 \mathrm{ab}$ & $15.58 \pm 15.48 \mathrm{ab}$ & $10.26 \pm 8.32 \mathrm{ab}$ \\
\hline $\mathrm{Na}$ & $0.31 \pm 0.44 c$ & $0.51 \pm 0.59 \mathrm{~b}$ & $0.23 \pm 0.16 c$ & $0.58 \pm 0.22 \mathrm{a}$ & $0.13 \pm 0.09 c$ \\
\hline $\mathrm{Mg}$ & $1.20 \pm 0.65 \mathrm{a}$ & $0.33 \pm 0.26 b$ & $0.49 \pm 0.70 \mathrm{~b}$ & $0.95 \pm 0.63 \mathrm{a}$ & $0.66 \pm 0.40 \mathrm{ab}$ \\
\hline $\mathrm{Al}$ & $1.58 \pm 2.15 \mathrm{ab}$ & $1.99 \pm 1.86 \mathrm{a}$ & $1.03 \pm 0.77 \mathrm{ab}$ & $2.29 \pm 0.79 \mathrm{a}$ & $0.55 \pm 0.55 \mathrm{~b}$ \\
\hline $\mathrm{Fe}$ & $1.37 \pm 0.86 \mathrm{a}$ & $0.45 \pm 0.43 b$ & $0.41 \pm 0.38 b$ & $0.98 \pm 0.58 \mathrm{a}$ & $0.63 \pm 0.41 \mathrm{ab}$ \\
\hline $\mathrm{Mn}$ & $0.48 \pm 0.26 \mathrm{a}$ & $0.17 \pm 0.14 b$ & $0.22 \pm 0.36 b$ & $0.26 \pm 0.23 b$ & $0.16 \pm 0.13 b$ \\
\hline
\end{tabular}

The values present the means $\pm \mathrm{SD} ; n=45$. Different lowercase letters indicate that there is a significant difference between the annual amount of each element returned.

\section{Results}

\subsection{Litter Input and Composition}

The annual litter input of the different components and the total annual litter input followed the same patterns. The amount of input from the different litter components was ranked as follows: leaves $>$ branches $>$ epiphytes. The amount of leaf litter was significantly higher than the amount of epiphyte litter $(p<0.05)$; the maximum leaf litter amount $\left(2174.51 \mathrm{~kg} \cdot \mathrm{ha}^{-1}\right)$ was recorded in October 2016 , while the minimum $\left(256.31 \mathrm{~kg} \cdot \mathrm{ha}^{-1}\right)$ was recorded in May 2016 (Figure 2). Leaves were the main components of litterfall in the Minjiang forest, accounting for 34\% 79\% of the total litterfall, followed by branches; epiphytes accounted for the smallest proportion of litter, at only 3\% 31\% (Figure 5). The seasonal litter amount exhibited a low positive correlation with seasonal mean temperature and a low negative correlation with seasonal total precipitation, while the annual litter amount had a high negative correlation with annual total precipitation (Table 1). The litter input tended to be greater in the nongrowing season than in the growing season. The litter inputs were higher in the nongrowing season than in the growing season in 2016, 2017 and 2019, with nongrowing season values of $2743.34,3029.03$ and $2888.99 \mathrm{~kg} \cdot \mathrm{ha}^{-1}$, respectively. There were significant differences in the litter between the growing season and the nongrowing season in 2016 and 2017 (Figure 3). Among the 10 litter inputs in the different seasons, the litter input in the nongrowing season in 2017 was the greatest, with a significantly higher value than that in the growing seasons in 2016, 2017, 2018 and 2020 as well as that in the nongrowing seasons in 2018 and 2020. There were also differences in the annual litter input over the past five years. The annual litter input in 2019 was $5384.15 \mathrm{~kg} \cdot \mathrm{ha}^{-1}$, which was significantly higher than that in 2016, 2018 and 2020; the annual litter input in 2017 was $3976.08 \mathrm{~kg} \cdot \mathrm{ha}^{-1}$, which was significantly higher than that in $2018(p<0.05)$. 


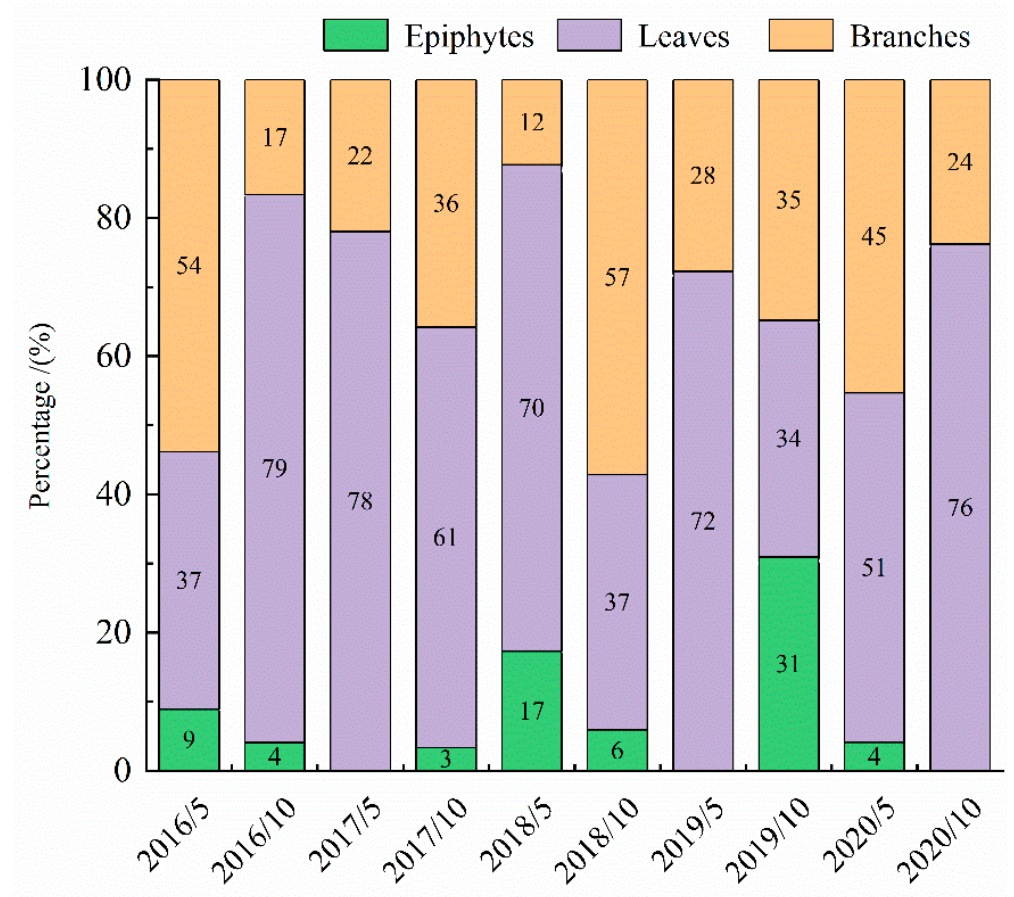

Figure 5. Proportions and production of each litter component from 2016 to 2020 in the A. faxoniana forest. The values represent the means $\pm \mathrm{SD} ; n=45$.

\subsection{Element Contents of Litter}

The contents of $\mathrm{C}, \mathrm{N}$ and $\mathrm{P}$ in the litter of the Minjiang Abies faxoniana forest ranged from 300 to $525 \mathrm{~g} \cdot \mathrm{kg}^{-1}$, from 6 to $15 \mathrm{~g} \cdot \mathrm{kg}^{-1}$, and from 0.3 to $1.0 \mathrm{~g} \cdot \mathrm{kg}^{-1}$, respectively. Time had a significant effect on the contents of $\mathrm{C}, \mathrm{N}$ and $\mathrm{P}$. The contents of $\mathrm{K}, \mathrm{Mg}$, $\mathrm{Al}$ and $\mathrm{Fe}$ in the different litter components were highest in epiphytes, followed by branches and leaves, and time had a significant effect on the contents of these elements. The $\mathrm{Ca}$ and Mn contents in the different litter components were highest in the leaves, followed by epiphytes and branches. The Mn content was significantly affected by time and component, while Ca was significantly affected by only component. The Na content was highest in epiphytes, followed by leaves and branches, and time had a significant effect on $\mathrm{Na}$ contents (Figure 4).

\subsection{Element Return Amount of Litter}

The dynamics of $\mathrm{C}, \mathrm{N}$ and $\mathrm{P}$ returned from litter were consistent with the annual inputs of litter, with both the return and the input exhibiting years with large and small amounts. There were significant differences in the return amount of each element among different components and different years. Time had an extremely significant effect on the return amount of each metal element $(p<0.01)$, and the return amount of each metal element in the nongrowing season was significantly greater than that in the growing season in the same year. Litter composition had significant effects on the returned amounts of $\mathrm{K}, \mathrm{Ca}$, $\mathrm{Na}$, $\mathrm{Mg}$, $\mathrm{Al}$ and $\mathrm{Mn}(p<0.05)$, with leaves providing significantly more element return than branches and epiphytes. In particular, the amount of $\mathrm{N}$ returned to the ecosystem by leaves was significantly higher than that returned by branches and epiphytes. Differences in the return amount were observed for the same component in different years (Table 2). Among the returned amounts of the metal elements, the most obvious fluctuations were observed for Ca. The maximum return amount was $18.88 \mathrm{~kg} \cdot \mathrm{ha}^{-1}$ in 2016 , and the minimum was $7.04 \mathrm{~kg} \cdot \mathrm{ha}^{-1}$ in 2017 . The element with the lowest return amount and the smallest fluctuations was $\mathrm{Mn}$; the maximum return amount of this element was $0.48 \mathrm{~kg} \cdot \mathrm{ha}^{-1}$ in 2016 , with returned amounts of approximately $0.20 \mathrm{~kg} \cdot \mathrm{ha}^{-1}$ in the other four years. 


\section{Discussion}

\subsection{Litter Input Production}

Litter plays an important role in material cycling and energy flow in forest systems and is representative of the ecological functions of plant communities and ecosystems [30]. This study found that in the five years from 2016 to 2020, the annual litter input was between 2055.96 and $5384.15 \mathrm{~kg} \cdot \mathrm{ha}^{-1} \cdot \mathrm{a}^{-1}$, which was consistent with the research of Peng et al. [31]. Fluctuating trends in the amount of annual litter maybe the major reason and different precipitation also have some impacts on the wide range of litter production. With the lowest annual total precipitation, the maximum litter production occurred in 2019 due to the high negative correlation between the annual litter amount and annual total precipitation. The average annual litter yield was $3472.73 \mathrm{~kg} \cdot \mathrm{ha}^{-1} \cdot \mathrm{a}^{-1}$, which was lower than the yield observed by Yang et al. [32] (3839.68 $\mathrm{kg} \cdot \mathrm{ha}^{-1} \cdot \mathrm{a}^{-1}$ ) at low altitudes in the same region. This result is consistent with the findings of Wei Li that forest litter input gradually decreases with increasing latitude and altitude [33]. The main component of the litter was leaves, which accounted for an average of $2131.42 \mathrm{~kg} \cdot \mathrm{ha}^{-1} \cdot \mathrm{a}^{-1}$; this value is higher than the yield observed in a subalpine forest in the western Himalayas of India by Sanjay et al. [34] and consistent with the results of previous studies on the litter yield range of Minjiang fir forests [35]. There were significant differences in litter input among different components in the Minjiang fir forest, and the contribution of leaves to litter was significantly higher than that of epiphytes. This may be because leaves play a central role in metabolic processes and are key to daily plant activities. Moreover, the proportion of epiphytes in forest ecosystems is much lower than that of branches and leaves. There are obvious seasonal dynamics in litter quantity [36], but there are few studies on the annual and seasonal dynamics of litter, and the focus has been primarily on the monthly dynamics of litter. Qi et al. [37] collected litter from a subalpine forest ecotone in a subalpine ecosystem every month for two consecutive years to study its properties. Chave et al. [38] studied the seasonal characteristics and relationship between litter and rainfall by analysing litter collected monthly; Zhang et al. [39] discussed the seasonal characteristics of litter from four seasons by comparing the monthly litter of different types of forests. In the present study, litter from the fir forest was monitored continuously for five years by sampling twice per year: in the growing season and the nongrowing season. Comparisons of the amounts of litterfall indicated that the litter in the nongrowing season generally contributed more than the litter in the growing season; this finding was consistent with the research of Cui et al. [40], who showed that the peak litter input amount in a subalpine coniferous forest occurred in October. However, over two years, the amount of litter input in the nongrowing season was slightly lower than that in the growing season, which may be due to the greater precipitation that occurred in the growing season from 2018 to 2020. In addition to the negative correlation between precipitation and seasonal litter amount, green litter may also influence litter production, which was mentioned by Fu [41]. Moreover, the seasonal litter amount has a negative correlation with precipitation, which was greater in 2018 and 2020.

\subsection{Element Contents and Returned Amounts of Litterfall}

The contents of nutrient elements in litter are mainly affected by the physiological functions of nutrient element [42,43]. We found that the element contents in the litter from the Minjiang fir forest were ranked as follows: $\mathrm{C}>\mathrm{Ca}>\mathrm{N}>\mathrm{K}>\mathrm{Al}>\mathrm{Fe}>\mathrm{Mg}>\mathrm{Na}>\mathrm{P}>\mathrm{Mn}$; this finding was consistent with those reported in previous research [30,44,45]. The carbon content in the leaf litter ranged from 324.11 to $490.13 \mathrm{~g} \cdot \mathrm{kg}^{-1}$, which was slightly lower than the average carbon content of fresh leaves $\left(489.12 \pm 6.87 \mathrm{~g} \cdot \mathrm{kg}^{-1}\right)$ reported in a subalpine coniferous forest [46]. The carbon content of litter collected in the growing season was generally higher than that of litter collected in the nongrowing season, which is consistent with previous research results [45]. This difference may have occurred because leaves are the main site of photosynthesis in plants, and photosynthesis is greater at the higher temperatures that occur in the growing season; in addition, leaf metabolism is more vigorous during the growing season than during the nongrowing season $[47,48]$. The dynamics of 
the litter element return were approximately the same as the dynamics of litter input, and the average annual returns of $\mathrm{C}, \mathrm{N}$ and $\mathrm{P}$ were $1402.40,32.48$ and $2.00 \mathrm{~kg} \cdot \mathrm{ha}^{-1} \cdot \mathrm{a}^{-1}$, respectively, which were lower than those of litter from an evergreen plantation [49]. Among the metal elements, Ca exhibited the maximum fluctuation, and Mn exhibited the minimum fluctuation. In addition, the dynamics of all the metal elements followed a bimodal pattern, which is consistent with the conclusions obtained by previous studies [50,51]. There were also differences in the return amount of the same element among the different litter components. The amounts of $\mathrm{C}, \mathrm{N}$ and $\mathrm{P}$ returned by leaves were significantly higher than those returned by epiphytes, which might be because the input amount of leaves was significantly higher than that of epiphytes $(p<0.05)$. This result is also consistent with the findings of previous studies, which showed that the amount of litterfall affects the element return amount $[1,52]$.

\section{Conclusions}

The litter yield and return amount in the Minjiang fir forest differed significantly with time and component. Generally, the litterfall yield and return amount of each element followed the same bimodal pattern. Furthermore, litter inputs and element return amounts in the nongrowing season were greater than those in the growing season. These differences may have implications for nutrient cycling in belowground environments and plant growth in aboveground environments. The Minjiang fir forest is the main vegetation type in the southwestern forest region of China and the coniferous species with the highest altitude in western Sichuan. Long-term monitoring of litter yield, carbon and nutrient element contents and their returns is of great importance because it can provide data on and a basis for monitoring material cycling and fills a knowledge gap with respect to alpine forest ecosystems.

Author Contributions: Methodology, Y.L., Y.C., S.H.; conceptualization, Y.L., Y.C.; funding acquisition, Y.L.; data collection, Y.C., L.W., Y.Z. (Yu Zhou); sample processing, L.W., S.H., Y.Z. (Yu Zhou); laboratory experiments, Y.Z. (Yu Zhou), Y.Z. (Yabei Zhang), W.W.; supervision, J.Z.; writing-original draft, W.W., Y.Z. (Yabei Zhang); writing-review \& editing, Y.L., Lifeng Wang, Y.Z. (Yu Zhou), Y.C. All authors have read and agreed to the published version of the manuscript.

Funding: This research was funded by projects from the Science and Technology Development Project of the central government guided in Sichuan [2020ZYD049] and the National Natural Science Foundation of China [31570605].

Institutional Review Board Statement: Not applicable.

Informed Consent Statement: Not applicable.

Data Availability Statement: All data included in this study are available upon request by contact with the corresponding author.

Conflicts of Interest: The authors declare that they have no conflicts of interest.

\section{References}

1. Yang, G.L.; Li, J.Q.; Zuo, M. Study on litter input dynamics and nutrient return of Pinus yunnanensis forest in Mopanshan, Central Yunnan Plateau. Ecol. Environ. Sci. 2019, 28, 2158-2164.

2. Li, Q.; Zhou, D.W.; Chen, X.Y. Accumulation and decomposition of above-ground litter and its role in terrestrial ecosystems. Acta Ecol. Sin. 2014, 34, 3807-3819.

3. Cole, D.M.; Rapp, M. Elemental cycling in forest ecosystems. In Dynamic Properties of Forest Ecosystems; Reichle, D.E., Ed.; Cambridge University Press: Cambridge, UK, 1981; Volume 23, pp. 341-409.

4. Wang, X.D.; Zhu, W.Z.; Chen, G.W. Progress of observation experiment and research on alpine ecosystem of Gongga Mountain. J. Mt. Sci. 2006, 05, 612-619.

5. Bradford, M.A.; Berg, B.; Maynard, D.S.; Wieder, W.R.; Wood, S.A. Understanding the dominant controls on litter decomposition. J. Ecol. 2016, 104, 229-238. [CrossRef]

6. Zhu, X.; Zhang, W.; Jiang, X.; Zakari, S.; Lu, E.; Singh, A.K.; Yang, B.; Liu, W. Conversion of primary tropical rainforest into rubber plantation degrades the hydrological functions of forest litter: Insights from experimental study. Catena 2021, 200, 105172. [CrossRef] 
7. Fan, Z.P.; Wang, Q.; Li, F.Y. Seasonal dynamics and driving factors of soil organic carbon in different forest types in the mountainous area of eastern Liaoning Province. J. Ecol. 2018, 37, 3220-3230.

8. Qing, Q.Q.; Wang, H.Y. Spatial variability of forest litter nutrients and its influencing factors. J. Ecol. 2020, 39, 1318-1329.

9. Zhou, G.; Guan, L.; Wei, X.; Zhang, D.; Zhang, Q.; Yan, J.; Wen, D.; Liu, J.; Liu, S.; Huang, Z.; et al. Litterfall production along successional and altitudinal gradients of subtropical monsoon evergreen broadleaved forests in Guangdong, China. Plant Ecol. 2007, 188, 77-89. [CrossRef]

10. Fajardo, A.; Piper, F.I.; Cavieres, L.A. Distinguishing local from global climate influences in the variation of carbon status with altitude in a tree line species. Glob. Ecol. Biogeogr. 2011, 20,307-318. [CrossRef]

11. Millard, P.; Sommerkorn, M.; Grelet, G.A. Environmental change and carbon limitationgan in trees: A biochemical, ecophysiological and ecosystem appraisal. New Phytol. 2007, 175, 11-28. [CrossRef]

12. Wang, J.P.; Wu, Y.H. Effects of phosphorus bioavailability on mountain ecosystem. Acta. Ecol. Sin. 2016, 36, 1204-1214.

13. He, X.H. Nickel—Essential metal element for plants. Bioscience 1993, 3, 45.

14. Verbruggen, N.; Hermans, C. Physiological and molecular responses to magnesium nutritional imbalance in plants. Plant Soil 2013, 368, 87-99. [CrossRef]

15. Zhou, Y.; Wang, L.; Chen, Y.; Zhang, J.; Liu, Y. Litter stoichiometric traits have stronger impact on humification than environment conditions in an alpine treeline ecotone. Plant Soil 2020, 453, 545-560. [CrossRef]

16. Kaspari, M. The seventh macronutrient: How sodium shortfall ramifies through populations, food webs and ecosystems. Ecol. Lett. 2020, 23, 1153-1168. [CrossRef]

17. Paudel, E.; Dossa, G.G.; Xu, J.; Harrison, R.D. Litterfall and nutrient return along a disturbance gradient in a tropical montane forest. For. Ecol. Manag. 2015, 353, 97-106. [CrossRef]

18. Lukumbuzya, T.K.; Fyles, J.W.; Cote, B. Effects of base-cation fertilization on litter decomposition in a sugar maple forest in southern Quebec. Can. J. For. Res. 1994, 24, 447-452. [CrossRef]

19. Ahirwal, J.; Saha, P.; Nath, A.; Nath, A.J.; Deb, S.; Sahoo, U.K. Forests litter dynamics and environmental patterns in the Indian Himalayan region. For. Ecol. Manag. 2021, 499, 119612. [CrossRef]

20. Zheng, H.; Chen, Y.; Liu, Y.; Heděnec, P.; Peng, Y.; Xu, Z.; Tan, B.; Zhang, L.; Guo, L.; Wang, L.; et al. Effects of Litter Quality Diminish and Effects of Vegetation Type Develop During Litter Decomposition of Two Shrub Species in an Alpine Treeline Ecotone. Ecosystems 2021, 24, 197-210. [CrossRef]

21. Wang, L.; Chen, Y.; Zhou, Y.; Zheng, H.; Xu, Z.; Tan, B.; You, C.; Zhang, L.; Li, H.; Guo, L.; et al. Litter chemical traits strongly drove the carbon fractions loss during decomposition across an alpine treeline ecotone. Sci. Total Environ. 2021, $753,142287$. [CrossRef]

22. Wang, L.; Chen, Y.; Zhou, Y.; Xu, Z.; Tan, B.; You, C.; Zhang, L.; Li, H.; Zheng, H.; Guo, L.; et al. Environmental conditions and litter nutrients are key determinants of soluble C, N, and P release during litter mixture decomposition. Soil Tillage Res. 2021, 209, 104928. [CrossRef]

23. Wang, L.; Zhang, J.; He, R.; Chen, Y.; Yang, L.; Zheng, H.; Li, H.; Xiao, J.; Liu, Y. Impacts of soil fauna on lignin and cellulose degradation in litter decomposition across an alpine forest-tundra ecotone. Eur. J. Soil Biol. 2018, 87, 53-60. [CrossRef]

24. Kaspari, M.; Garcia, M.N.; Harms, K.E.; Santana, M.; Wright, S.J.; Yavitt, J.B. Multiple nutrients limit litterfall and decomposition in a tropical forest. Ecol. Lett. 2008, 11, 35-43. [CrossRef]

25. Luciana, S.; Valentini, C.M.A.; Pinto, O.B.P. Seasonal and interannual litter dynamics of a tropical semideciduous forest of the southern Amazon Basin, Brazil. J. Geophys. Res. Biogeosci. 2008, 113, G4.

26. Kubota, Y.; Narikawa, A.; Shimatani, K. Litter dynamics and its effects on the survival of Castanopsis sieboldii seedlings in a subtropical forest in southern Japan. Ecol. Res. 2007, 22, 792-801. [CrossRef]

27. Zhu, J.; He, X.; Wu, F.; Yang, W.; Tan, B. Decomposition of Abies faxoniana litter varies with ferrze-thaw stages and altitudes in subalpine forests of southwest China. Scand. J. For. Res. 2012, 27, 586-596. [CrossRef]

28. Fanin, N.; Fromin, N.; Buatois, B.; Hättenschwiler, S. An experimental test of the hypothesis of non-homeostatic consumer stoichiometry in a plant litter-microbe system. Ecol. Lett. 2013, 16, 764-772. [CrossRef]

29. Zeng, X.; Fu, C.K.; Yang, J.P. Restitution dynamics of $\mathrm{K}$ and $\mathrm{Na}$ of litter in a primary forest of Sequoia chinensis and Abies minjiang. J. Ecol. 2020, 39, 1426-1435.

30. Weltzin, J.F.; Keller, J.K.; Bridgham, S.D.; Pastor, J.; Allen, P.B.; Chen, J. Litter controls plant community composition in a northern fen. Oikos 2005, 110, 537-546. [CrossRef]

31. Pen, G.Q.; Cui, X.; Wu, C.C.; Yang, D.M. Study on litter quantity and seasonal dynamic variation of Abies fargesii Forest at Different Altitudes in Minjiang River. Shaanxi For. Sci. Technol. 2011, 4, 1-4.

32. Yang, J.P.; Liao, R.; Yang, W.Q.; Tan, B.; Fu, C.K.; Zhang, Y.; Wu, F.Z. Litter yield and dynamics of dark coniferous forest in alpine canyon region. Chin. J. Appl. Environ. Biol. 2017, 23, 103-107.

33. Li, W.; Luo, J.; Cheng, G.W.; Song, M.Q. Characteristics of litterfall in Abies emei forest of Gongga Mountain. J. Mt. Sci. 2003, 21, 287-292.

34. Gairola, S.; Rawal, R.S.; Dhar, U. Patterns of litterfall and return of nutrients across anthropogenic disturbance gradients in three subalpine forests of west Himalaya, India. J. For. Res. 2009, 14, 73-80. [CrossRef]

35. Yang, Y.S.; Chen, Y.X.; Chen, G.S.; Guo, J.F.; Zheng, Y.M. Comparison of litter decomposition and nutrient dynamics of Chinese fir plantation in Fujian. For. Sci. 2004, 40, 2-10. 
36. Seta, T.; Demissew, S.; Woldu, Z. Litterfall dynamics in boter-becho borest moist evergreen montane forest of Southwestern Ethiopia. J. Ecol. Nat. Environ. 2018, 10, 13-21.

37. Qi, M.Z.; Wang, K.Y. Dynamics of litter yield and nutrient return in the subalpine timberline ecotone of western Sichuan. J. Ecol. 2010, 29, 434-438.

38. Chave, J.; Navarrete, D.; Almeida, S.; Álvarez, E.; Aragão, L.E.; Bonal, D.; Châtelet, P.; Silva-Espejo, J.E.; Goret, J.Y.; Hildebrand, P.V.; et al. Regional and seasonal patterns of litterfall in tropical South America. Biogeosciences 2017, 7, 43-55. [CrossRef]

39. Zhang, H.C.; Yuan, W.P.; Dong, W.J.; Liu, S. Seasonal patterns of litterfall in forest ecosystem worldwide. Ecol. Complex. 2014, 14, 884-892. [CrossRef]

40. Cui, B.H.; Jiang, Y.; Chen, S.W.; Jin, M.R.; Hu, K.B.; Wang, S.Q. Dynamics of litter yield and nutrient return in subalpine coniferous forest and coniferous and broad-leaved mixed forest in western Sichuan. Sichuan For. Sci. Technol. 2012, 33, 16-20.

41. Fu, C.K. Effects of Forest Gap on Litter Production and Element Return in Alpine Forest. Ph.D. Thesis, Sichuan Agricultural University, Chengdu, China, 2018.

42. Vasconcelos, H.L.; Luizão, F.J. Litter production and litter nutrient concentrations in a fragmented Amazonian land. Ecol. Appl. 2014, 14, 884-892. [CrossRef]

43. Samuelsonlisa, J.; Stokestom, A.; Butnorjohn, R. Eco system carbon stocks in Pinus palustris forests. Can. J. For. Res. 2014, 44, 476-486. [CrossRef]

44. González-Rodríguez, H.; Domínguez-Gómez, T.G.; Cantú-Silva, I.; Gómez-Meza, M.V.; Ramírez-Lozano, R.G.; Pando-Moreno, M.; Fernández, C.J. Litterfall deposition and leaf litter nutrient return in different locations at Northeastern Mexico. Plant Ecol. 2011, 212, 1747-1757. [CrossRef]

45. Yang, H.; Yin, C.Y.; Zhen, D.H.; Tang, B.; Zhao, W.Q.; Li, N.; Pu, X.Z.; Liu, Q. Stoichiometric characteristics of leaf C, N and P in growing and non-growing seasons of Picea spruce and Abies in subalpine coniferous forests of western Sichuan. Chin. J. Appl. Environ. Biol. 2017, 23, 1089-1095.

46. Pan, Y.; Bai, H.T.; Li, H. Effects of cultivation area, harvest season and plant age on the composition and antibacterial activity of essential oil from rosemary. Acta Bot. Sin. 1998, 22, 566-570.

47. Fu, C.; Yang, W.; Tan, B.; Xu, Z.; Zhang, Y.; Yang, J.; Ni, X.; Wu, F. Seasonal dynamics of litterfall in a subalpine spruce-fir forest on the eastern Ti-betan Plateau: Allometric scaling relationships based on one year of observations. Forests 2017, 8, 314. [CrossRef]

48. Neumann, M.; Ukonmaanaho, L.; Johnson, J.; Benham, S.; Vesterdal, L.; Novotný, R.; Verstraeten, A.; Lundin, L.; Thimonier, A.; Michopoulos, P.; et al. Quantifying carbon and nutrient input from litterfall in European forests using field observations and modeling. Glob. Biogeochem. Cycles 2018, 32, 784-798. [CrossRef]

49. Wang, J.L.; Tao, L.; Lu, Z.W. Characteristics of litterfall in spruce forest in Nyingchi, Tibet. Chin. J. Plant Ecol. 1998, 22, 566-570.

50. Liu, W.F.; Fan, H.B.; Shen, F.F.; Huang, R.Z.; Yuan, Y.H.; Li, Y.Y.; Liao, Y.C. Study on litter decomposition in eucalyptus plantation with continuous age series. J. Soil Water Conserv. 2010, 24, 132-136.

51. Osono, T.; Takeda, H. Organic chemical and nutrient dynamics in decomposing beech leaf litter in relation to fungal ingrowth and succession during 3-year decomposition processes in a cool temperate deciduous forest in Japan. Ecol. Res. 2001, 16, 649-670. [CrossRef]

52. Asigbaase, M.; Dawoe, E.; Lomax, B.H.; Sjogersten, S. Temporal changes in litterfall and potential nutrient return in cocoa agroforestry systems under organic and conventional management, Ghana. Heliyon 2021, 7, e08051. [CrossRef] [PubMed] 